\title{
PENGARUH KETERAMPILAN BERBICARA TERHADAP SIKAP MORAL YANG DIMILIKI SISWA SMP KOTA SUKABUMI
}

\author{
Egi Nusivera \\ Tina Rosalina \\ Universitas Muhamadiyah Sukabumi \\ (eghie_nusivera06@yahoo.com)
}

\begin{abstract}
ABSTRAK
Penelitian ini bertujuan untuk mendeskripsikan ketampilan berbicara yang dimiliki oleh siswa SMP Kota Sukabumi, dan mendeskripsikan pengaruh keterampilan berbicara dan sikap moral yang dimiliki siswa SMP kota Sukabumi. Penelitian ini adalah penelitian yang menggabungkan dua bidang ilmu yaitu bahasa dan pendidikan kewarganegaraan. Penelitian ini adalah penelitian deskriptif kualitatif yang menggunakan metode survei. Dalam penelitian ini, data yang diambil berupa data dari sekolah, guru, dan siswa Sekolah Pertama Kota (SMP) Sukabumi tahun pelajaran 2014. Sumber data dalam penelitian ini dipilih secara acak, sekolah- sekolah tersebut meliputi SMP Negeri 2, SMP Negeri 4, SMP Negeri 7, dan SMP Islam Nur Karomah Kota Sukabumi. Teknik pengumpulan data dalam penelitian ini dilakukan melalui observasi, angket wawancara langsung. Dalam penelitian ini ditemukan bahwa keterampilan berbicara pada siswa SMP Kota Sukabumi dipengaruhi oleh beberapa faktor yaitu faktor lingkungan sekolah, faktor lingkungan di luar sekolah dan, faktor keluarga. Karena moral merupakan standar baik- buruk yang ditentukan bagi individu sebagai anggota sosial, maka faktor tersebut sangat mempengaruhi sikap moral yang dimiliki siswa dalam kesehariannya.
\end{abstract}

Kata kunci: keterampilan berbicara, sikap moral. 


\section{A. PENDAHULUAN}

Kegiatan mengajar yang dilaksanakan di sekolah dapat diartikan sebagai suatu proses interaksi antara siswa dengan guru, untuk mencapai tujuan belajar yang sebaik- baiknya. Dalam proses interaksi ini, keterampilan berbahasa sangat diperlukan. Terlebih lagi pada keterampilan berbicara. Karena berbicara merupakan suatu keterampilan berbahasa yang berkembang pada anak, yang hanya didahului oleh keterampilan menyimak dan pada masa tersebut kemampuan berbicara dan berujar dipelajari (Tarigan, 1990: 3). Dalam lingkungan pendidikan, siswa dituntut terampil berbicara dalam proses pembelajaran. Akan tetapi, siswa yang terampil berbicara belum tentu memiliki sikap moral yang baik pula.

Karena moral berkaitan dengan kehidupan sosial secara harmonis, adil, dan seimbang. Perilaku moral diperlukan demi terwujudnya kehidupan yang damai penuh keteraturan, ketertiban,merupakan kaidah norma dan pranata yang mengatur perilaku individu dalam kehidupannya dengan kelompok sosial dan masyarakat. Moral merupakan standar baik-buruk yang ditentukan bagi individu sebagai anggota sosial. Moralitas merupakan aspek kepribadian yang diperlukan seseorang dan keharmonisan.Memperhatikan gejala- gejala yang tampak pada masa sekarang, cenderung banyak siswa dari Sekolah Menengah Pertama (SMP) kurang memperhatikan etika yang berlaku disekolah, hal ini dapat kita lihat dari tingkah laku siswa sehari- hari seperti cara berpakaian, terlebih lagi pada cara bertuturkatanya baik itu dengan teman sebaya maupun dengan yang lebihtua.

Dalam penelitian ini, peneliti mencoba mengaitkan keterampilan berbicara dengan sikap yang dimiliki siswa, perlu dipertimbangkan waktu, tempat, dan pada siapa mereka berbicara. Karena sikap yang dimiliki siswa mempengaruhi pilahan kata dan ungakapan yang nantinya digunakan dalam percakapan. Berdasarkan alasan tersebut, maka akan diadakan penelitian yang berjudul "Pengaruh Keterampilan Berbicara Dengan Sikap Moral yang Dimiliki Siswa SMP Negeri di Kota Sukabumi”.

Berdasarkan latar belakang masalah, penulis merumuskan permasalahan yaitu: (1) Bagaimana keterampilan berbahasa yang dimiliki 
siswa SMP se-Kota Sukabumi? (2) Bagaimana pengaruh keterampilan berbahasa dengan sikap yang dimiliki siswa SMP se-Kota Sukabumi?. Tujuan dari penelitian ini adalah (1) mendeskripsikan kemampuan keterampilan berbicara yang dimiliki siswa di dalam kelas padasiswa SMP Negeri di Kota Sukabumi (2) mendeskripsikan pengaruh keterampilan berbicara dengan sikap yang dimiliki siswa SMP Negeri di Kota Sukabumi. Ada pun landasan teori pada penelitian ini mencakup kemampuan berbicara, sikap, dan moral.

Berbicara merupakan kemampuan mengucapkan bunyi-bunyi artikulasi atau kata-kata untuk mengekspresikan, menyatakan serta menyampaikan pikiran, gagasan dan perasaan (Tarigan, 1993:15). Pendapat yang sama disampaikan oleh Tarigan, dkk (1997:13). Mereka berpendapat bahwa berbicara adalah keterampilan menyampaikan pesan melalui bahasa lisan kepada orang lain. Sedangkan Maidar (1988:17) mengemukakan kemampuan berbicara merupakan kemampuan mengucapkan bunyi- bunyi artikulasi atau mengucapkan kata- kata untuk mengekspresikan, menyatakan, menyampaikan pikiran, gagasan, dan perasaan. Pendapat di atas pada dasarnya sama saja, yakni berbicara merupakan keterampilan atau kemampuan untuk menyampaikan pesan berupa pikiran, gagasan dan perasaan melalui bahasa lisan kepada orang lain. Pendengar menerima informasi melalui rangkaian nada, tekanan, dan ketepatan persendian. Jika komunikasi berlangsung secara tatap muka, dengan gerak tangan dan air muka (mimik) pembicara.

Tujuan utama dari pembicara adalah untuk berkomunikasi. Agar dapat menyampaikan informasi dengan efektif, sebaiknya pembicara betul- betul memahami isi pembicaraannya, disamping itu juga dapat mengevaluasi efek komunikasinya terhadap pendengar. Jadi bukan hanya apa yang akan dibicarakan, tetapi bagaimana mengemukakannya.

Kemampuan berbahasa seseorang dalam berbicara pada dasarnya dapat dibedakan menjadi dua kelompok, yaitu kemampuan memahami, dan menggunakan yang masing- masing bersifat reseptif dan produktif. Kemampuan reseptif yaitu proses usaha memahami apa yang dituturkan orang lain. Sebaliknya, kemampuan produktif yaitu usaha mengkomunikasikan ide pikiran atau perasaan melalui bentuk- bentuk kebahasaan. Dalam kegiatan 
berbicara diperlukan penguasaan terhadap lambang bunyi, baik untuk keperluan menyampaikan atau menerima gagasan. Lambang yang berupa tanda- tanda visual seperti yang dibutuhkan dalam kegiatan membaca menulis tidak diperlukan. Itulah sebabnya, orang yang buta huruf pun dapat melakukan aktivitas berbicara secara baik.

Prinsip pembelajaran berbicara menurut Daniel (1996:29-30) sebagai berikut: (1) berbicara tercirikan oleh pertemuan antara dua orang atau lebih yang melangsungkan komunikasi secara lisan, ada pembicara dan ada pendengar, (2) ada banyak tipe dalam komunikasi lisan anatara pembicara dan pendengar, mulai dari dua orang berbincang-bincang sampai kepertemuan umum lapangan, (3) pembelajaran berbicara tidak dapat mencakup semua variasi atau tipe pertemuan lisan itu, (4) pembelajaran berbicara bersifat fungsional.

Untuk dapat menjadi pembicara yang baik, seorang pembicara selain harus memberikan kesan bahwa ia menguasai masalah yang dibicarakan, si pembicara juga harus memperlihatkan keberanian dan kegairahan. Selain itu pembicara dengan jelas dan tepat. Dalam hal ini menurut Maidar (1988:17-22) mengemukakan ada beberapa faktor yang harus diperhatikan oleh si pembicara untuk keefektifan berbicara, yaitu faktor kebahasaan dan nonkebahasaan.

1. Faktor Kebahasaan

a. Ketepatan Ucapan

Seseorang pembicara harus membiasakan diri mengucapkan bunyibunyi bahasa secara tepat. Pengucapan bunyi bahasa yang kurang tepat dapat mengalihkan perhatian pendengar. Masing- masing kita mempunyai gaya tersebahasa sendiri dan gaya bahasa yang kita pakai berubah- ubah sesuai dengan pokok pembicaraan, perasaan, dan sasaran. Akan tetapi, kalau perbedaan atau perubahan itu terlalu mencolok, sehingga menjadi suatu penyimpangan, maka keefektifan komunikasi akan terganggu.

b. Penempatan Tekanan, Nada, Sendi, dan Durasi yang Sesuai

Kesesuaian tekanan, nada, sendi, dan durasi akan merupakan daya tarik sendiri dalam berbicara. Bahkan kadang- kadang merupakan faktor penentu. 
Walaupun masalah yang dibicarakan kurang menarik, dengan penempatan tekanan, nada, sendi, dan durasi yang sesuai akan menyebabkan masalahnya menjadi menarik. Sebaliknya jika disampaikan datar saja, hampir dapat dipastikan akan menimbulkan kejemuan dan keefektifan berbicara tentu berkurang.

\section{c. Pilihan kata (Diksi)}

Pilihan kata hendaknya tepat, jelas, dan bervariasi. Jelas maksudnya mudah dimengertioleh pendengar yang menjadi sasaran. Pendengar akan lebih terangsang dan akan lebih paham, kalau kata- kata yang digunakan kata-kata yang sudah dikenal oleh pendengar. Kata- kata yang belum dikenal memang membangkitkan rasa ingin tahu, namun akan menghambat kegiatan berkomunikasi. Selain itu, hendaknya dipilih kata- kata yang konkret sehingga mudah dipahami pendengar. Kata- kata konkret yang menunjukkan aktivitas akan lebih mudah dipahami pembicara. Namun, pilihan kata itu tentu harus kita sesuaikan dengan pokok pembicaraan dan dengan siapa kita berbicara. Dalam hal ini hendaknya pembicara menyadari siapa pendengarnya dan apa pokok pembicaraannya, dan menyesuaikan pilihan katanya dengan pokok pembicaraan dan pendengarnya.

\section{d. Ketepatan Sasaran Pembicaraan}

Hal ini menyangkut pemakaian kalimat. Pembicara yang menggunakan kalimat efektif akan memudahkan pendengar menangkap pembicaraannya. Seorang pembicara harus mampu menyusun kalimat efektif, kalimat yang mengenai sasaran, sehingga mampu menimbulkan pengaruh, meninggalkan kesan, atau menimbulkan akibat.

\section{Faktor Nonkebahasaan}

a. Sikap yang Wajar, Tenang, dan Tidak Kaku

Pembicara yang tidak tenang, lesu, dan kaku tentulah akan memberikan kesan pertama yang kurang menarik. Padahal kesan pertama ini sangat penting untuk menjamin adanya kesinambungan perhatian pihak pendengar. 
Penguasaan materi yang baik, setidaknya akan menghilangkan kegugupan. Namun bagaimana pun, sikap ini memerlukan latihan. Kalau sudah biasa, lama- kelamaan rasa gugupakan hilang dan akan timbul sikap tenang dan wajar.

\section{b. Pandangan Harus Diarahkan kepada Lawan Bicara}

Supaya pendengar dan pembicara betul- betul terlibat dalam kegiatan berbicara, pandangan pembicara sangat membantu. Hal ini sering diabaikan oleh pembicara. Pandangan yang hanya tertuju pada satu arah, akan menyebabkan pendengar merasa kurang diperhatikan.

c. Kesediaan Menghargai Pendapat Orang Lain.

Dalam menyampaikan isi pembicaraan, seorang pembicara hendaknya memiliki sikap terbuka dalam arti dapat menerima pendapat dari pihak lain, bersedia menerima kritik, bersedia mengubah pendapatnya kalau ternyata memang keliru. Namun, tidak berarti si pembicara begitu saja mengikuti pendapat orang lain dan mengubah pendapatnya, tetapi ia juga harus mampu mempertahankan pendapatnya dan meyakinkan orang lain.

\section{d. Gerak- Gerik dan Mimik yang Tepat}

Gerak- gerik dan mimik yang tepat dapat pula menunjang keefektifan berbicara. Hal- hal yang penting selain mendapatkan tekanan, biasanya juga dibantu dengan gerak tangan atau mimik. Hal ini dapat menghidupkan komunikasi, artinya tidak kaku. Akan tetapi, gerak gerik yang berlebih akan mengganggu keefektifan berbicara.

\section{e. Kenyaringan Suara}

Tingkat kenyaringan suara tentu disesuaikan dengan situasi, tempat, jumlah pendengar, dan akustik. Tetapi perlu diperhatikan jangan berteriak. Kita aturlah kenyaringan suara kita supaya dapat didengar oleh semua pendengar dengan jelas, dengan juga mengingat kemungkinan gangguan dari luar. 


\section{f. Kelancaran}

Seorang pembicara yang lancar mencakup isi pembicaraannya. Seringkali kita dengar pembicara berbicara terputus- putus, bahkan antara bagian- bagian yang terputus itu diselipkan bunyi- bunyi tertentu yang sangat mengganggu penangkapan pendengar, misalnya menyelipkanbunyi ee,oo,aa, dan sebagainya. Sebaliknya pembicara yang terlalu cepat berbicara juga akan menyulitkan pendengar untuk menangkap pokok pembicaraan.

\section{g. Relevansi/ Penalaran}

Gagasan demi gagasan haruslah berhubungan dengan logis. Proses berfikir untuk sampai pada satu kesimpulan haruslah logis. Hal ini berarti hubungan bagian- bagian dalam kalimat, hubungan kalimat dengan kalimat harus logis dan berhubungan dengan pokok pembicaraan.

\section{h. Penguasaan Topik}

Pembicaraan formal selalu menuntut persiapan. Tujuannya tidak lain supaya topik dipilih benar- benar dikuasai. Penguasaan topik yang baik akan menumbuhkan keberanian dan kelancaran. Jadi, penguasaan topik ini sangat penting, bahkan merupakan faktor utama dalam berbicara.

Ada tiga konsep yang masing-masing mempuyai makna, pengaruh, dan konsekuensi yang besar terhadap perkembangan perilaku individu, termasuk juga perilaku remaja.

\section{Nilai}

Dalam kamus bahasa Indonesia, nilai adalah harga, angka kepandaian. Adapun menurut Spranger, nilai diartikan sebagai suatu tatanan yang dijadikan panduan oleh individu untuk menimbang dan memilih alternatif keputusan dalam situasi sosial tertentu. Dalam perspektif Spranger, kepribadian manusia terbentuk dan berakar pada tatanan nilai-nilai dan kesejahteraan. Meskipun menempatkan konteks sosial sebagai dimensi nilai dalam kepribadian manusia, tetapi spranger tetap mengakui kekuatan individual yang dikenal dengan istilah “ roh subjektif” (subjective spirit)dan kekuatan nilai-nilai budaya merupakan 
"roh objektif" (objevtive spirit). Roh objektif akan berkembang manakala didukung oleh roh subjektif, sebaliknya roh subjektif terbentuk dan berkembang dengan berpedoman kepada roh objektif yang diposisikan sebagai cita-cita yang harus dicapai.

2. Moral

Istilah moral berasal dari kata Latin Mores yang artinya tata cara dalam kehidupan, adat istiadat, atau kebiasaan. Maksud moral adalah sesuai dengan ide-ide yang umum diterima tentang tindakan manusia mana yang baik dan wajar. Moral merupakan kaidah norma dan pranata yang mengatur perilaku individu dalam kehidupannya dengan kelompok sosial dan masyarakat. Moral merupakan standar baik-buruk yang ditentukan bagi individu sebagai anggota sosial. Moralitas merupakan aspek kepribadian yang diperlukan seseorang dalam kaitannya dengan kehidupan sosial secara harmonis, adil, dan seimbang. Perilaku moral diperlukan demi terwujudnya kehidupan yang damai penuh keteraturan, ketertiban, dan keharmonisan.

\section{Sikap}

Sikap tidak identik dengan respons dalam bentuk perilaku, tidak dapat diamati secara langsung tetapi dapat disimpulkan dari konsistensi perilaku yang dapat diamati. Secara operasional, sikap dapat diekspresikan dalam bentuk kata-kata atau tindakan yang merupakan respons reaksi dari sikapnya terhadap objek, baik berupa orang, peristiwa, atau situasi. Menurut Suke Silverius (dalam Riyono, 2005:11), sikap meliputi lima tingkat kemampuan yaitu:

\section{Menerima (Receiving)}

Tingkat ini berhubungan dengan kesediaan atau kemauan siswa untuk ikut dalam suatu fenomena atau stimulus khusus. Misalnya dalam kegiatan pembelajaran di kelas. Kata-kata kerja operasional yang dapat digunakan untuk rumusan indikatornya adalah menanyakan, menyebutkan, mengikuti, dan menyeleksi.

2. Menanggapi / Menjawab (Responding) 
Pada tingkatan ini, siswa tidak hanya menghadiri suatu fenomena tetapi juga bereaksi terhadapnya. Kata-kata kerja operasional yang dapat digunakan untuk rumusan indikatornya adalah menjawab, berbuat, melakukan, dan menyenangi.

\section{Menilai (Valuing)}

Tingkat ini berkenaan dengan nilai yang dikenakan siswa terhadap sesuatu obyek atau fenomena tertentu. Tingkai ini berjenjang mulai dari hanya sekedar penerimaan sampai pada tingkat komitmen yang lebih tinggi. Kata-kata kerja operasional yang dapat digunakan untuk rumusan indikatornya adalah membedakan, mempelajari, dan membaca.

4. Organisasi (Organization)

Hasil belajar pada tingkat ini berkenaan dengan organisasi suatu nilai (merencanakan suatu pekerjaan yang memenuhi kebutuhannya). Kata-kata kerja operasional yang dapat digunakan untuk rumusan indikatornya adalah menyiapkan, mempertahankan, mengatur, menyelesaikan, dan menyusun.

5. Karakteristik dengan suatu nilai atau kompleks nilai

Hasil belajar pada tingkat ini meliputi banyak kegiatan, tapi penekanannya lebih besar diletakkan pada kenyataan banhwa tingkah laku itu menjadi ciri khas atau karakteristik siswa tersebut. Kata-kata kerja operasional yang dapat digunakan untuk rumusan indikatornya adalah menerapkan, membenarkan cara pemecahan masalah, dan sebagainya.

Jenis penelitian yang akan dilaksanakan dalam penelitian ini adalah penelitian survei dengan menggunakan metode deskriptif. Jenis penelitian survei ini, merupakan penelitian yang mengumpulkan informasi tentang karakteristik, tindakan, pendapat dari sekelompok responden yang representatif yang dianggap sebagai populasi. Penelitian survei menghasilkan deskripsi beberapa aspek dari populasi yang dipelajari dan memerlukan informasi dari subjek yang dipelajari. Selain itu penelitian survei juga bertujuan untuk mengumpulkan informasi tentang variabel dari sekelompok objek atau populasi.

Dalam penelitian ini, data yang diambil berupa data dari sekolah, guru, dan siswa Sekolah Pertama Kota Sukabumi tahun pelajaran 
2014.Sumber data dalam penelitian ini dipilih secara acak, sekolah- sekolah tersebut meliputi SMP Islam Nurul Karomah, SMP Negeri 2, SMP Negeri 3, SMP Negeri 11, dan SMP Negeri 7 Kota Sukabumi. Teknik pengumpulan data dalam penelitian ini dengan menggunakan angket, lembar observasi, wawancara dan dokumentasi. Dan hasil dari wawancara tersebut peneliti akan dianalisis tiga siklus yaitu reduksi data, penyajian data, serta varifikasi data atau penarikan kesimpulan dalam penelitian.

\section{B. PEMBAHASAN}

Penelitian ini dilakukan pada lima sekolah sampel. Sekolah sampel tersebut dipilih melalui pengklasifikasian asumsi masyarakat yang memenilai sekolah tersebut favorit, menengah, dan tarafnya lebih rendah yang dipih secara acak. Sekolah tersebut terdiri dari SMP N 2 Sukabumi, SMP N 4 Sukabumi, SMP N 7 Sukabumi, SMP N 11 Sukabumi, dan SMP Islam Nurul Karomah. Dalam penelitian ini peneliti menemukan beberapa faktor yang mempengaruhi sikap berbicara siswa.

Menurut Show dan Wright (dalam Azwar,1992) menerangkan bahwa sikap memiliki referensi atau kelas referensi yang spesifik dan membatasi konstruksi sikap komponen afektif saja. Lebih jauh mereka mengemukakan, aspek afektif ini mendahului tingkah laku dan didasarkan pada proses kognitif. Pada aspek kognitif dilihat dari representasi apa yang dipercayai oleh individu pemilik sikap, komponen kognitif berisi kepercayaan yang dimiliki individu mengenai sesuatu dapat disamakan penanganan (opini) terutama apabila menyangkut masalah isu atau problem yang kontroversial.

Lima sekolah yang diteliti, pada lingkungan sekolah kegiatan berkomunikasi dan berbicara yang dilakukan oleh siswa sudah memiliki komponen kognitifnya. Telihat dari kegiatan komunikasi yang berlangsung di dalam kelas, terjadinya interaksi yang baik antara guru dan siswa, dan juga antara siswa dengan siswa lainnya. Contohnya saja pada proses pembelajaran berlangsung, terjadinya diskusi tentang materi yang diberikan pada saat itu. Walaupun terdapat siswa yang kurang aktif bertanya kepada guru, akan tetapi aspek kognitif berbicara antar siswa satu dengan yang lainnya. 
Komponen afektif menurut Menurut Show dan Wright (dalam Azwar,1992) juga merupakan perasaan yang menyangkut aspek emosional. Aspek emosional inilah yang biasanya berakar paling dalam sebagai komponen sikap dan merupakan aspek yang paling bertahan terhadap pengaruh-pengaruh yang mungkin adalah mengubah sikap seseorang komponen afektif disamakan dengan perasaan yang dimiliki seseorang terhadap sesuatu.

Hasil dari penelitian yang telah dilakukan pada sikap afektif ini terdapatnya perubahan tingkah laku siswa dalam berbicara di lingkungan sekolah dengan diluar sekolah. Jika di dalam lingkungan sekolah kegiatan berbicara siswa lebih terkontrol karena adanya guru yang mengawasi baik itu di luar kelas maupun di dalam kelas. Akan tetapi jika diluar sekolah sikap berbicara yang dimiliki siswa berpengaruh oleh lingkungan pertemanannya dan lingkungan keluarga. Menurut penelitian yang telah dilakukan, 50\% dari siswa yang diteliti memiliki pergaulan yang terpengaruh oleh zaman. Kegiatan berbicaranya pun cendrung kasar. Akan tetapi, dilihat dari sekolah yang bertaraf tinggi sebagian besar siswa memiliki kemampuan berbicara yang santun. Hal tersebut juga dipengaruhi oleh lingkungan keluarga. Di lingkungan keluarga yang menengah keatas siswa terbiasa untuk berbicara santun, dan sikap yang ditunjukkan siswa di lingkungan sekolah pun sama dengan sikap yang ada di luar lingkungan sekolah.

Dari lima sekolah yang diteliti, peneliti mengambil salah satu sampel sekolah islam, yaitu SMP Islam Nur Karolama. Dari hasil penelitian yang dilakukan, kemampuan berbicara dan sikap moral yang baik yang dimiliki oleh siswa juga dipengaruhi oleh pelajaran agama yang didapat oleh siswa disekolah. Karena adanya pelajaran- pelajaran agama yang menjadi pondasi siswa, siswa lebih matang dalam cara bersikap dan berbicara. Baik itu dengan yang lebih tua, dengan yang seumur dan yang lebih muda. Selain sekolah agama tersebut empat sekolah negeri yang diteliti juga memasukkan unsur pelajaran agama dan kegiatan agama yang diharapkan akan membentuk siswa itu sendiri. Akan tetapi dari letak sekolah juga mempengaruhi cara berbicara siswa, contohnya saja pada SMPN 11 yang berlokasi pinggir pasar dan stasiun. Hal itu mempengaruhi sikap berbicara siswa. Kurang dari 50\% siswa memiliki 
sikap dan kemampuan berbicara yang sedikit kasar walaupun seringkali ditegur oleh gurunya. Akan tetapi lingkungan sekitar sekolah sangat mempengaruhi sikap siswa.

\section{PENUTUP}

Penelitian ini dapat ditarik kesimpulan yaitu ada beberapa faktor yang mempengaruhi kemampuan berbicara dan sikap moral yang dimiliki siswa,yaitu lingkungan sekolah, lingkungan diluar sekolah, lingkungan keluarga, serta adanya pelajaran agama yang didapat oleh siswa itu sendiri.

Saran yang dapat diberikan dalam penelitian ini adalah lebih ditingkatkan lagi pengawasan guru yang berperan sebagai orang tua yang mengawasi siswa disekolah, dan di lingkungan keluarga orang tua juga lebih meningkatkan lagi pengawasan terhadap anak. Agar kemampuan berbicara siswa dengan sikap moral yang dimilikinya akan seimbang apabila anak diberikan pelajaran dan pengetahuan yang positif yang akan membuat pemikiran anak lebih positif dan akhirnya memiliki kemampuan berbicara dan sikap moral yang baik.

\section{DAFTAR PUSTAKA}

Ali, Mohammad dan Asrori, Muhammad, 2006, Psikologi Remaja, Jakarta:PTBumi.

Arikunto, Suhasimi. 2006. Prosedur Penelitian Suatu Pendekatan Praktik. Jakarta: Rienika Cipta.

Corey, Gerald, 2009, Teori dan Praktek KONSELING DAN PSIKOTERAPI, Bandung: PT RefikaAditama

Furchan, Arif. Pengantar Penelitian Dalam Pendidikan.Surabaya:Usaha Nasional Offset Printing

Hurlock, Elizabeth B. 1980, Psikologi Perkembangan, Jakarta: Erlangga.

Makmun, Abin Syamsudin; 1981. Psikologi Kependidikan ; Bandung ; IKIP Bandung.

Rahayu, Minto. 2007. Bahasa Indonesia Di Perguruan Tinggi. Jakarta: Garasindo. 
Sugiyono. 2008. Metode Penelitian Kuantitatif Kualitatif dan R\&D. Bandung: Alfabeta.

Sukmadinata, Nana Syaodih. 2008. Metode Penelitian Pendidikan.

Semiawan, Conny R (1999) Perkembangan dan Belajar Peserta Didik.Jakarta:

Depdikbud

Sapa'at, Asep. 2008. Guru Sebagai Agen Pembelajar, (http://matematika.upi.edu, diakses 9 Juli 2014).

Tarigan, Henry Guntur. 1990. Berbicara Suatu Keterampilan Berbahasa, Bandung: Angkasa.

Tarigan, Henry Guntur, dkk. 1987. Teknik Keterampilan Berbahasa. Bandung: Angkasa.

Wahab, Abdul Azis dkk; 1986. Kurikulum dan Buku Teks PMP.Modul 1-3,4-6; Jakarta. Depdikbud Universitas Terbuka. 